\title{
Causes of respiratory failure in COVID-19 patients
}

\author{
Amr El-Sayed ${ }^{1} \cdot$ Mohamed M. Abdel-Daim ${ }^{2} \cdot$ Mohamed Kamel $^{1}$ (i) \\ Received: 16 November 2020 / Accepted: 27 April 2021 / Published online: 5 May 2021 \\ (C) The Author(s), under exclusive licence to Springer-Verlag GmbH Germany, part of Springer Nature 2021
}

\section{Introduction}

Severe acute respiratory syndrome coronavirus 2 (SARSCoV-2), which was reported in 2019 in Wuhan, China, causes the coronavirus disease (COVID-19) pandemic (Baloch et al. 2020 ). It has spanned nearly $108,026,145$ million people around the world, with 2,369,067 million deaths by the day of 11 February 2021, and continues to increase. It restricted the travel for most of the global population over the past year. COVID-19 is now the top wellbeing, fiscal, and healthcare concern throughout the modern age.

With full genetic sequence details, SARS-CoV-2 can be identified as a member of the subgenus Sarbecovirus in the Coronaviridae family. It codes its RNA genome for 4 structural and 16 non-structural proteins (Fig. 1) (Asrani et al. 2020; Schoeman and Fielding 2019; Huang et al. 2020; Sarkar and Saha 2020). Structural proteins include spike (S), envelope (E), nucleocapsid $(\mathrm{N})$, and membrane $(\mathrm{M})$ proteins (Boson et al. 2020; Thomas 2020; Gupta 2020). The coronavirus protein $\mathrm{S}$ gives the surface appearance of the spike crown and is important to recognize host receptors, host repertoire, binding, viral tissue tropism, entry, fusion and activation of $\mathrm{T}$ cell responses, and antibody neutralization (Huang et al. 2020; Sternberg and Naujokat 2020; Chambers et al. 2020). The $M$ protein is the basic type component of the surface of the virus, which delineates inflammatory responses and generates ribonucleoproteins. Although $\mathrm{N}$ protein facilitates its entrance and survival inside the host cells, the

Amr El-Sayed and Mohamed Kamel contributed equally to this work.

Responsible Editor: Philippe Garrigues

Mohamed Kamel

m_salah@cu.edu.eg

1 Department of Medicine and Infectious Diseases, Faculty of Veterinary Medicine, Cairo University, Giza 12211, Egypt

2 Pharmacology Department, Faculty of Veterinary Medicine, Suez Canal University, Ismailia 41522, Egypt
E protein increases its pathogenicity and acts as an ion channel (Huang et al. 2020; Sarkar and Saha 2020; Wang et al. 2020). SARS-CoV-2 adapts to a variety of hosts due to high mutation rates (Sarkar and Saha 2020; Huang et al. 2020) (13). Different forms of vaccines are being produced to defend against COVID-19. The vaccines included inactivated, DNA, mRNA, viral vector, saRNA, and protein subunits (DeFrancesco 2020; Lundstrom 2020; Pushparajah et al. 2021; Sanicas et al. 2020; Sarkar and Saha 2020; Tregoning et al. 2020). While some vaccines are already approved, others are still being developed or tested clinically (DeFrancesco 2020; Lundstrom 2020; Pushparajah et al. 2021; Sanicas et al. 2020; Sarkar and Saha 2020; Tregoning et al. 2020; Li et al. 2020b). Potency, safety, and purity are the main concerns in vaccine evaluation. Despite the available control measures, deaths are still ongoing. We highlighted here on the different factors triggering respiratory failure due to COVID19 infecton as the main cause of death and the deteminants of its susceptibility in a population is also focused.

\section{Factors determining COVID-19 susceptibility in the population}

Since the emergence of SARS-CoV-2 in 2019, about 2,369,067 persons died until the date. Due to the high binding affinity of SARS-CoV-2 to angiotensin-converting enzyme 2 (ACE2) receptors which are expressed by different tissues, SARS-CoV-2 has a broad tissue tropism and can attack various systems of the body. Therefore, infection with SARS$\mathrm{CoV}-2$ can result in wide range of clinical signs. The patients may demonstrate one or more of the following symptoms: respiratory manifestations (Zheng et al. 2020), gastrointestinal symptoms and hepatic abnormalities (Zarifian et al. 2020), integumentary system and skin lesions (e.g., pityriasis rosea, exanthem, papules, vesicles, and urticaria) (Rodriguez-Cerdeira et al. 2021; Deshmukh et al. 2020), multisystem inflammatory syndrome and Kawasaki-like 


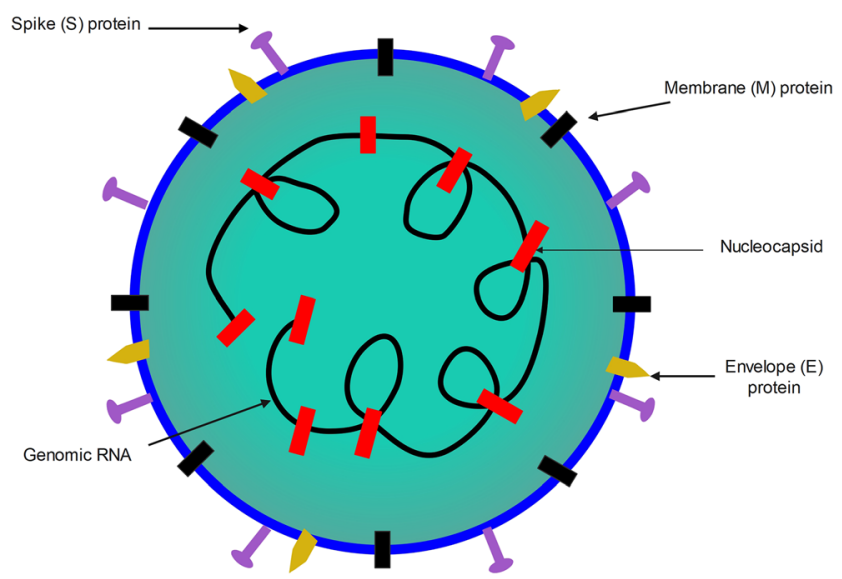

Fig. 1 Schematic structure of SARS-CoV-2

syndrome in children (Esmaeilzadeh et al. 2021; Haslak et al. 2020), nervous signs (Soltani et al. 2021; Ellul et al. 2020), severe immune response (storm of cytokines) (Hu et al. 2021), and cardiovascular manifestations (Israel et al. 2021) and may even infect the male reproductive system leading to testicular damage and reduction of male fertility (Roychoudhury et al. n.d.; Tian and Zhou 2021).

According to literature, SARS-CoV-2 can initiate clinical signs or complications in other organs in seldom cases, such as the induction of renal papillary necrosis (Tallai et al. 2021), thyroid dysfunction (Lui et al. 2021), or systemic mastocytosis (Slaibi et al. 2021). While some patients remain clinically asymptomatic, others must be hospitalized and even intubated. The individual susceptibility to COVID-19 in the population varies according to several factors. In other words, there are many risk factors which influence COVID-19 prevalence among individuals and among population. Within the same population, factors as age, sex, weight, and health status play a major role in the determination of disease severity (high-risk individuals: males, old age, overweight, history of chronic diseases as diabetes, cardiovascular diseases, or asthma). Similarly, other factors determine disease susceptibility among different populations including population density, percentage of youth in the population, traditional diet/gut microbiota, lifestyle, genetic factors including ethnic differences, and the share of Neanderthals DNA in the genome (Giudicessi et al. 2020; Shelton et al. 2020; Bhopal and Bhopal 2020; Nelson 2020; Woolf et al. 2021; Hamer et al. 2020).

\section{Causes of respiratory failure in COVID-19 patients}

As mentioned above, SARS-CoV-2 can infect several body systems and induce life-threatening clinical signs. Death can result from cardiovascular events (e.g., stroke and acute coronary syndrome), severe uncontrolled immune response (cytokine storm), damage of the brain stem, or respiratory failure (Wu et al. 2021; Solomon 2021).

Respiratory failure is one of the major causes of COVID-19 induced mortalities. However, the high mortality rate even among intubated ICU patients proves the multifactorial nature of the COVID-19 respiratory failure (Fig. 2) so that other therapeutic approaches must be developed including the use of hymecromone and cortisone (Hellman et al. 2020).

Among these factors: (A) cardiovascular factors (Fig. 3): (1) production of bradykinin and inflammatory mediators, which increase the permeability of blood vessels, leads to the accumulation of fluids in air alveoli. The resulting pulmonary oedema interferes with gas exchange and results in hypoxaemia; (2) the accumulation of exudates/fluids in the lungs accompanied with inflammatory pulmonary oedema results additionally in pulmonary hypertension. The stagnation and slowing of the circulation exert an additional load/overload on right heart volume (Duan et al. 2020); (3) the interference with gas exchange and the resulting hypoxaemia creates a state of imbalance of oxidation and antioxidation system in the myocardium. This, in turn, provokes the accumulation of reactive oxygen species (ROS), destroys the cardiomyocyte cell membrane, and initiates the programmed cell death. The damaging effects of ROS in cardiomyocytes extend also to involve transport system of calcium ions. The resulting intracellular chaos includes the activation of sarcoplasmic reticulum $\mathrm{Ca}^{+}$-ATPase accompanied with the reduction of intracellular $\mathrm{Ca}^{+}$level, the inactivation of $\mathrm{Ca}^{+}$-ATPase in cardiomyocytes cell membrane, opening the receptors of melastain 2 cation channel, and enhancing $\mathrm{Ca}^{+}{ }^{+}$loading ending with cardiomyocyte apoptosis (Duan et al. 2020); (4) increased production of hyaluronic acid which interacts with the fluids in the alveoli producing hydrogel (hyaluronan-based jelly) (Garvin et al. 2020; Hellman et al. 2020; van Dam et al. 2020), and (5) arterial and venous thrombosis of the pulmonary vessels which lead to pulmonary embolism and tissue ischemia. The thrombi in small pulmonary vessels are secondary to endothelial damage due to viral infection (harbor expressed ACE2 receptors) or due to alveolar damage and the deposition of alveolar fibrin (thromboinflammatory syndrome) (Lax et al. 2020; Wu et al. 2021). (B) Neurotropism of the brainstem which enhances viral invasion. The resulting permanent damage of the brainstem responsible for normal breathing can explain why some of the recovered patients from COVID-19 pneumonia remain in dependable on mechanical ventilation (Manganelli et al. 2020). The virus can invade the CNS via hematogenous and nervous routes. This occurs following damage of the BBB caused by the auto-immune response (Scoppettuolo et al. 2020), transportation of the virus with infected WBCs to the brain, or due to the direct interaction between viral S protein and ACE2 receptors (Wu et al. 2020) or via the trans-synaptic route (olfactory bulb) (Brann et al. 
Fig. 2 Factors trigerring and causing respiratory failure in COVID-19 infected patients

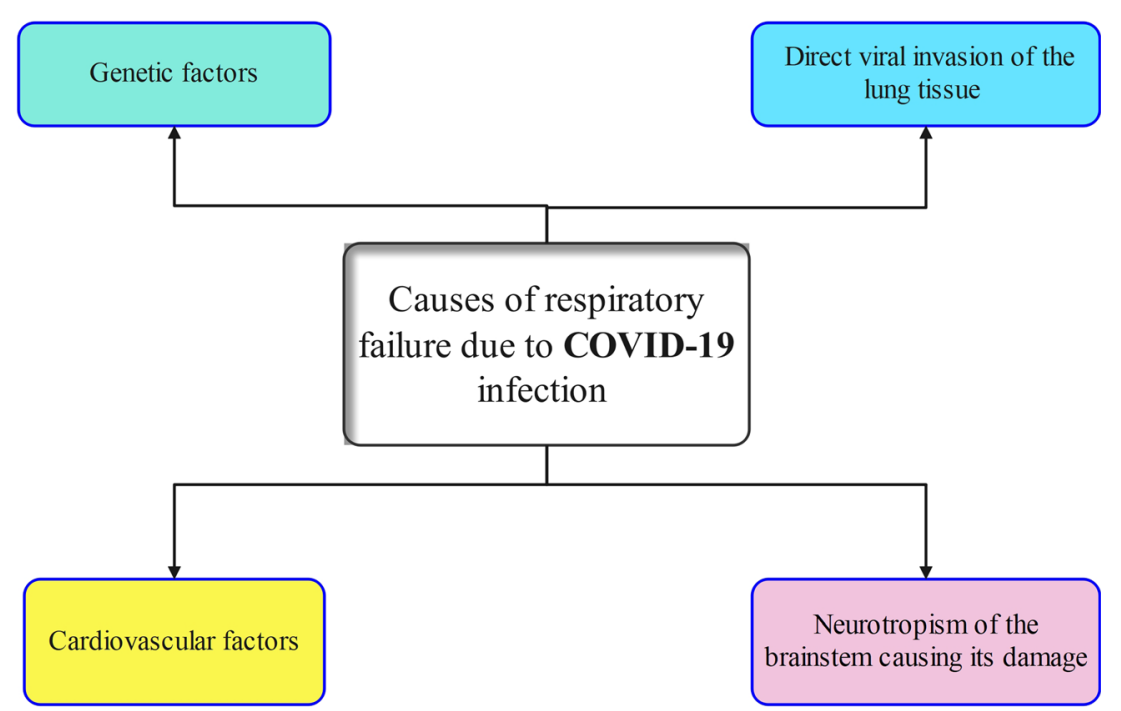

2020). The resulting damages include encephalopathy (no direct CNS invasion occurs) and encephalitis (induced by direct viral invasion to CNS) (Poyiadji et al. 2020; Koralnik and Tyler 2020). Additional nervous damage due to intracranial cytokine storms can complicate the situation (Poyiadji et al. 2020). (C) Direct viral invasion of the lung tissue is facilitated by the presence of ACE2 receptors in airway epithelium, lung parenchyma, and endothelial cells. Severe alveolar damage and consolidation of lung parenchyma were common findings of post-mortal studies where bilateral diffuse alveolar damage, fibrosis, oedema, proliferation of pneumocytes and fibroblasts, presence of pulmonary emboli, and infarctions were reported (Lax et al. 2020; Li et al. 2020a; Baig 2020). (D)
Genetic factors: relatively high percentage of patients who developed severe COVID-19 pneumonia harbored rare genetic variants in at least 13 genes regulating the immune response and interferon production. They produced auto-reactive antibodies which attack their immune system rather than the invading virus (Bastard et al. 2020). In addition, a clear relationship between the severity of the disease, asthma, and a predisposing genetic factor was also established among COVID-19 patients (Zhu et al. 2020).

In conclusion, understanding the underlying factors trigerring RF is very pivotal for treating COVID-19 patients. Trial to re-use and repurpose already available drugs or developing novel drugs targetting these factors will enhance
Fig. 3 Cardiovascular factors as a source of respiratory failure in COVID-19 infected patients

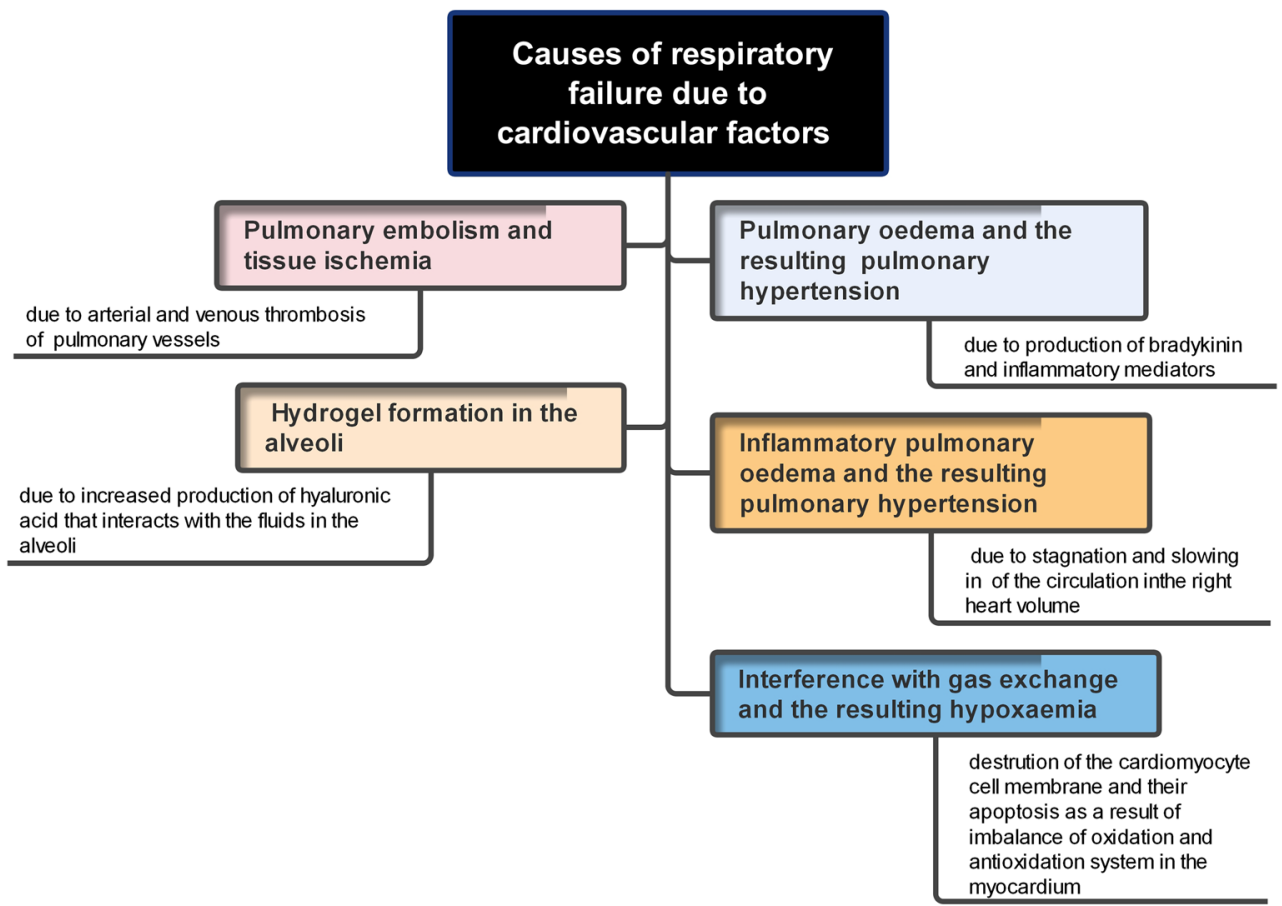


COVID-19 recovery and diminishing its effect. Cardiovascular factors, genetic factors, direct invasion of lung tissue, and permentnat damage of the brain stem are the main factors causing RF in COVID-19 infected patients. Factors affecting the susceptability to COVID-19 in a population should be taken into consideration in its control and preventative measures.

Availability of data and materials Not applicable.

Author contribution $\mathrm{AE}$ and $\mathrm{MK}$ : manuscript writing and revision. MMA conducted manuscript moderation and revision.

\section{Declarations}

Conflict of interest The authors declare no competing interests.

\section{References}

Asrani P, Hasan GM, Sohal SS, Hassan MI (2020) Molecular basis of pathogenesis of coronaviruses: a comparative genomics approach to planetary health to prevent zoonotic outbreaks in the 21 st century. Omics 24(11):634-644. https:// doi.org/10.1089/omi.2020.0131

Baig AM (2020) Computing the effects of SARS-CoV-2 on respiration regulatory mechanisms in COVID-19. ACS Chem Neurosci 11(16): 2416-2421. https://doi.org/10.1021/acschemneuro.0c00349

Baloch S, Baloch MA, Zheng T, Pei X (2020) The coronavirus disease 2019 (COVID-19) pandemic. Tohoku J Exp Med 250(4):271-278

Bastard P, Rosen LB, Zhang Q, Michailidis E, Hoffmann H-H, Zhang Y, Dorgham K, Philippot Q, Rosain J, Béziat V, Manry J, Shaw E, Haljasmägi L, Peterson P, Lorenzo L, Bizien L, Trouillet-Assant S, Dobbs K, de Jesus AA, Belot A, Kallaste A, Catherinot E, Tandjaoui-Lambiotte Y, Le Pen J, Kerner G, Bigio B, Seeleuthner Y, Yang R, Bolze A, Spaan AN, Delmonte OM, Abers MS, Aiuti A, Casari G, Lampasona V, Piemonti L, Ciceri F, Bilguvar K, Lifton RP, Vasse M, Smadja DM, Migaud M, Hadjadj J, Terrier B, Duffy D, Quintana-Murci L, van de Beek D, Roussel L, Vinh DC, Tangye SG, Haerynck F, Dalmau D, Martinez-Picado J, Brodin P, Nussenzweig MC, Boisson-Dupuis S, Rodríguez-Gallego C, Vogt G, Mogensen TH, Oler AJ, Gu J, Burbelo PD, Cohen JI, Biondi A, Bettini LR, D'Angio M, Bonfanti P, Rossignol P, Mayaux J, Rieux-Laucat F, Husebye ES, Fusco F, Ursini MV, Imberti L, Sottini A, Paghera S, Quiros-Roldan E, Rossi C, Castagnoli R, Montagna D, Licari A, Marseglia GL, Duval X, Ghosn J, Tsang JS, Goldbach-Mansky R, Kisand K, Lionakis MS, Puel A, Zhang S-Y, Holland SM, Gorochov G, Jouanguy E, Rice CM, Cobat A, Notarangelo LD, Abel L, Su HC, Casanova J-L (2020) Autoantibodies against type I IFNs in patients with life-threatening COVID-19. Science 370(6515): eabd4585. https://doi.org/10.1126/science.abd4585

Bhopal SS, Bhopal R (2020) Sex differential in COVID-19 mortality varies markedly by age. Lancet

Boson B, Legros V, Zhou B, Siret E, Mathieu C, Cosset F-L, Lavillette D, Denolly S (2020) The SARS-CoV-2 envelope and membrane proteins modulate maturation and retention of the Spike protein, allowing assembly of virus-like particles. J Biol Chem 296: 100111. https://doi.org/10.1074/jbc.RA120.016175
Brann DH, Tsukahara T, Weinreb C, Lipovsek M, van den Berge K, Gong B, Chance R, Macaulay IC, Chou H-J, Fletcher R, Das D, Street K, de Bezieux HR, Choi Y-G, Risso D, Dudoit S, Purdom E, Mill JS, Hachem RA, Matsunami H, Logan DW, Goldstein BJ, Grubb MS, Ngai J, Datta SR (2020) Non-neuronal expression of SARS-CoV-2 entry genes in the olfactory system suggests mechanisms underlying COVID-19-associated anosmia. bioRxiv: 2020.03.25.009084. doi: https://doi.org/10.1101/2020.03.25. 009084

Chambers JP, Yu J, Valdes JJ, Arulanandam BP (2020) SARS-CoV-2, early entry events. J Pathog 2020:1-11. https://doi.org/10.1155/ 2020/9238696

Deshmukh V, Motwani R, Kumar A, Kumari C, Raza K (2020) Histopathological observations in COVID-19: a systematic review. J Clin Pathol 74(2):76-83. https://doi.org/10.1136/jclinpath-2020206995

Duan J, Wu Y, Liu C, Yang C, Yang L (2020) Deleterious effects of viral pneumonia on cardiovascular system. Eur Heart J 41(19):18331838

Ellul MA, Benjamin L, Singh B, Lant S, Michael BD, Easton A, Kneen R, Defres S, Sejvar J, Solomon T (2020) Neurological associations of COVID-19. Lancet Neurol 19(9):767-783. https://doi.org/10. 1016/S1474-4422(20)30221-0

Esmaeilzadeh H, Mortazavi N, Salehi A, Fatemian H, Vardanjani HM (2021) Association of Kawasaki disease and COVID-19 in children. https://doi.org/10.21203/rs.3.rs-148574/v2

Garvin MR, Alvarez C, Miller JI, Prates ET, Walker AM, Amos BK, Mast AE, Justice A, Aronow B, Jacobson D (2020) A mechanistic model and therapeutic interventions for COVID-19 involving a RAS-mediated bradykinin storm. Elife 9:e59177. https://doi.org/ 10.7554/eLife.59177

Giudicessi JR, Roden DM, Am Wilde A, Ackerman MJ (2020) Genetic susceptibility for COVID-19-associated sudden cardiac death in African Americans. Heart Rhythm 17(9):1487-1492

Gupta SP (2020) Progress in studies on structural and remedial aspects of newly born coronavirus, SARS-CoV-2. Curr Top Med Chem 20(26):2362-2378. https://doi.org/10.2174/ 1568026620666200922112300

Hamer M, Gale CR, Kivimäki M, Batty GD (2020) Overweight, obesity, and risk of hospitalization for COVID-19: a community-based cohort study of adults in the United Kingdom. Proc Natl Acad Sci 117(35):21011-21013

Haslak F, Yildiz M, Adrovic A, Sahin S, Barut K, Kasapcopur O (2020) A recently explored aspect of the iceberg named COVID-19: multisystem inflammatory syndrome in children (MIS-C). Turk Arch Pediatr 55(1):3-9. https://doi.org/10.5152/TurkArchPediatr.2020. 20245

Hellman U, Karlsson MG, Engström-Laurent A, Cajander S, Dorofte L, Ahlm C, Laurent C, Blomberg A (2020) Presence of hyaluronan in lung alveoli in severe Covid-19 - an opening for new treatment options? J Biol Chem 295:15418-15422. https://doi.org/10.1074/ jbc.ac120.015967

Hu B, Huang S, Y in L (2021) The cytokine storm and COVID-19. J Med Virol 93(1):250-256. https://doi.org/10.1002/jmv.26232

Huang Y, Yang C, Xu X-F, Xu W, Liu S-W (2020) Structural and functional properties of SARS-CoV-2 spike protein: potential antivirus drug development for COVID-19. Acta Pharmacol Sin 41(9):11411149. https://doi.org/10.1038/s41401-020-0485-4

Koralnik IJ, Tyler KL (2020) COVID-19: a global threat to the nervous system. Ann Neurol 88(1):1-11. https://doi.org/10.1002/ana.25807

DeFrancesco L (2020) Whither COVID-19 vaccines? Nat Biotechnol 38(10):1132-1145. https://doi.org/10.1038/s41587-020-0697-7

Lax SF, Skok K, Zechner P, Kessler HH, Kaufmann N, Koelblinger C, Vander K, Bargfrieder U, Trauner M (2020) Pulmonary arterial thrombosis in COVID-19 with fatal outcome : results from a 
prospective, single-center, clinicopathologic case series. Ann Intern Med 173(5):350-361. https://doi.org/10.7326/M20-2566

Li Y-C, Bai W-Z, Hashikawa T (2020a) The neuroinvasive potential of SARS-CoV2 may play a role in the respiratory failure of COVID-19 patients. J Med Virol 92(6):552-555. https://doi.org/10.1002/jmv. 25728

Lui DTW, Lee CH, Chow WS, Lee ACH, Tam AR, Fong CHY, Law CY, Leung EKH, KKW T, Tan KCB, Woo YC, Lam CW, Hung IFN, Lam KSL (2021) Thyroid dysfunction in relation to immune profile, disease status, and outcome in 191 patients with COVID-19. J Clin Endocrinol Metab 106(2):e926-e935. https://doi.org/10. 1210/clinem/dgaa813

Lundstrom K (2020) The current status of COVID-19 vaccines. Front Genome Ed 2:10. https://doi.org/10.3389/fgeed.2020.579297

Manganelli F, Vargas M, Iovino A, Iacovazzo C, Santoro L, Servillo G (2020) Brainstem involvement and respiratory failure in COVID-19. Neurol Sci 41(7):1663-1665. https://doi.org/10.1007/s10072-02004487-2

Nelson R (2020) Risk variant for severe COVID-19 inherited from Neanderthals

Poyiadji N, Shahin G, Noujaim D, Stone M, Patel S, Griffith B (2020) COVID-19-associated acute hemorrhagic necrotizing encephalopathy: imaging features. Radiology 296(2):E119-E120. https://oi. org/10.1148/radiol.2020201187

Pushparajah D, Jimenez S, Wong S, Alattas H, Nafissi N, Slavcev RA (2021) Advances in gene-based vaccine platforms to address the COVID-19 pandemic. Adv Drug Deliv Rev 170:113-141. https:// doi.org/10.1016/j.addr.2021.01.003

Rodriguez-Cerdeira C, Uribe-Camacho BI, Silverio-Carrasco L, Méndez W, Mahesh AR, Tejada A, Beirana A, MartinezHerrera E, Alba A, Arenas R, Szepietowski JC (2021) Cutaneous manifestations in COVID-19: report on 31 cases from five countries. Biology (Basel) 10(1):54. https://doi.org/ 10.3390/biology10010054

Roychoudhury S, Das A, Jha NK, Kesari KK, Roychoudhury S, Jha SK, Kosgi R, Choudhury AP, Lukac N, Madhu NR, Kumar D, Slama P (n.d.) Viral pathogenesis of SARS-CoV-2 infection and male reproductive health. Open Biol 11(1):200347. https://doi.org/10.1098/ rsob.200347

Sanicas M, Sanicas M, Diop D, Montomoli E (2020) A review of COVID-19 vaccines in development: 6 months into the pandemic. Pan Afr Medic J 37:124. https://doi.org/10.11604/pamj.2020.37. 124.24973

Sarkar M, Saha S (2020) Structural insight into the role of novel SARSCoV-2 E protein: a potential target for vaccine development and other therapeutic strategies. PLoS One 15(8):e0237300. https://doi. org/10.1371/journal.pone.0237300

Schoeman D, Fielding BC (2019) Coronavirus envelope protein: current knowledge. Virol J 16:69. https://doi.org/10.1186/s12985-019$1182-0$

Scoppettuolo P, Borrelli S, Naeije G (2020) Neurological involvement in SARS-CoV-2 infection: a clinical systematic review. Brain, Behav, Immun - Health 5:100094. https://doi.org/10.1016/j.bbih.2020. 100094

Shelton JF, Shastri AJ, Ye C, Weldon CH, Filshtein-Somnez T, Coker D, Symons A, Esparza-Gordillo J, Aslibekyan S, Auton A (2020) Trans-ethnic analysis reveals genetic and non-genetic associations with COVID-19 susceptibility and severity. medRxiv

Slaibi A, Alshehabi Z, Soltany A, Isber Y, Eid R, Al-Armani A, Mohanna $\mathrm{F}$ (2021) A rare manifestation of indolent systemic mastocytosis and its management during the coronavirus disease 2019 pandemic; educational lessons from Syria. Ann Med Surg 62:293-297

Solomon T (2021) Neurological infection with SARS-CoV-2 — the story so far. Nat Rev Neurol 17(2):65-66. https://doi.org/10.1038/ s41582-020-00453-w
Soltani S, Tabibzadeh A, Zakeri A, Zakeri AM, Latifi T, Shabani M, Pouremamali A, Erfani Y, Pakzad I, Malekifar P, Valizadeh R, Zandi M, Pakzad R (2021) COVID-19 associated central nervous system manifestations, mental and neurological symptoms: a systematic review and meta-analysis. Rev Neurosci 32:351-361. https://doi.org/10.1515/revneuro-2020-0108

Sternberg A, Naujokat C (2020) Structural features of coronavirus SARSCoV-2 spike protein: targets for vaccination. Life Sci 257:118056. https://doi.org/10.1016/j.lfs.2020.118056

Tallai B, Gulistan TG, Alrayashi MNAB, Al Mughalles SAA, Kamkoum HM, Ebrahim MAA, Abdelkarim MAA, Salah MA (2021) A rare presentation of renal papillary necrosis in a COVID-19-positive patient. Case Rep Urol 2021:6611861-6611864. https://doi.org/10. $1155 / 2021 / 6611861$

Thomas S (2020) The structure of the membrane protein of SARS-CoV-2 resembles the sugar transporter semiSWEET. Pathog Immun 5(1): 342-363. https://doi.org/10.20411/pai.v5i1.377

Tian Y, Zhou L-Q (2021) Evaluating the impact of COVID-19 on male reproduction. Reproduction 161(2):R37-R44. https://doi.org/10. 1530/REP-20-0523

Tregoning JS, Brown ES, Cheeseman HM, Flight KE, Higham SL, Lemm N-M, Pierce BF, Stirling DC, Wang Z, Pollock KM (2020) Vaccines for COVID-19. Clin Exp Immunol 202(2):162-192. https://doi.org/10.1111/cei.13517

Israel V, Yogen S, Joan S-d-T, Paraskevi T, Ashish C, Sylvie DF, Beata K, Savina M, Amalia T-M, Federico G-L, Giridhar S, Kristof V, Francisco G-B, Joseph MMC, Simona M, Pace NC, Phuoc D, Giulia T, Antigoni D, Gauri N, Maria I, Paolo C, Owen M, Xavier I, Jelena H, Mariette KI, Sousa AR, Andrea D, Abigail S, Zdenka R, Francesca C, Daniel DW, Marisa V, Cecilia L, Ferran G, Constancio M-L, Almudena O-G, Vladislav V, Elisabeth BB, Ornella M, Wendy D, Begoña M, Emanuela V-B, Andreia F, Marie-Christine S, Isabelle L, Moises R-G, Maria RGS, Ziesenitz Victoria C, Giulia B, Gabriela D, Gernot G, Uaid FS, Viktor PK, Fernando C, Fatima P, Jussi N, Krishnan KH, Cecilia RP, Cezary N, Vincenzo ZG, Leoz GI, Madhu O, Catherine A, Karina B, Matteo C, Maria VA, Naga P, Roberta C, Davinder S, Saravanan D, Karen ML, Giulio C, Youssef Q, Marc G, Willem KT, Rita A, Marianna F, Tara B, Khushnood A, Alessandra MS, James W, Daniela I, Joan B, Nuria GV, Victorio C-P, Ivana C, Avishay S, Mahmoud Z, Elia S-V, Janet K-G, Faim D, Nathalie C, Mascart F, Fernando R-N, Matthias G, Alessandra G, Delia M, Martin K, Carlos A, Conceiçao T, Anita A, Katarina H (2021) Acute cardiovascular manifestations in 286 children with multisystem inflammatory syndrome associated with COVID-19 infection in Europe. Circulation 143(1):21-32. https:// doi.org/10.1161/CIRCULATIONAHA.120.050065

van Dam LF, Kroft LJM, van der Wal LI, Cannegieter SC, Eikenboom J, de Jonge E, Huisman MV, Klok FA (2020) Clinical and computed tomography characteristics of COVID-19 associated acute pulmonary embolism: a different phenotype of thrombotic disease? Thromb Res 193:86-89. https://doi.org/10.1016/j.thromres.2020. 06.010

Wang M-Y, Zhao R, Gao L-J, Gao X-F, Wang D-P, Cao J-M (2020) SARS-CoV-2: structure, biology, and structure-based therapeutics development. Front Cell Infect Microbiol 10:724. https://doi.org/10. 3389/fcimb.2020.587269

Woolf SH, Chapman DA, Lee JH (2021) COVID-19 as the leading cause of death in the United States. JAMA 325(2):123-124

Wu J, Mamas MA, Mohamed MO, Kwok CS, Roebuck C, Humberstone B, Denwood T, Luescher T, de Belder MA, Deanfield JE (2021) Place and causes of acute cardiovascular mortality during the COVID-19 pandemic. Heart 107(2):113-119

Wu Y, Xu X, Chen Z, Duan J, Hashimoto K, Yang L, Liu C, Yang C (2020) Nervous system involvement after infection with COVID-19 and other coronaviruses. Brain Behav Immun 87:18-22. https://doi. org/10.1016/j.bbi.2020.03.031 
Li Y-D, Chi W-Y, Jun-Han S, Ferrall L, Chien-Fu H, Wu T-C (2020b) Coronavirus vaccine development: from SARS and MERS to COVID-19. J Biomed Sci 27(1):1-23. https://doi.org/10.1186/ s12929-020-00695-2

Zarifian A, Zamiri Bidary M, Arekhi S, Rafiee M, Gholamalizadeh H, Amiriani A, Ghaderi MS, Khadem-Rezaiyan M, Amini M, Ganji A (2020) Gastrointestinal and hepatic abnormalities in patients with confirmed COVID-19: a systematic review and meta-analysis. J Med Virol 93:336-350. https://doi.org/10.1002/jmv.26314
Zheng Y, Wang L, Ben S (2020) Meta-analysis of chest CT features of patients with COVID-19 pneumonia. J Med Virol 93:241-249. https://doi.org/10.1002/jmv.26218

Zhu Z, Hasegawa K, Ma B, Fujiogi M, Camargo CA Jr, Liang L (2020) Association of asthma and its genetic predisposition with the risk of severe COVID-19. J Allergy Clin Immunol 146(2):327-329

Publisher's note Springer Nature remains neutral with regard to jurisdictional claims in published maps and institutional affiliations. 